$\stackrel{\odot}{\text { III }}$

\title{
MIASTO I MYŚLENIE PROJEKTOWE. DESIGN THINKING JAKO SKRZYNKA NARZĘDZIOWA
}

\begin{abstract}
Marta Skowrońska, Miasto i myślenie projektowe. Design thinking jako skrzynka narzędziowa [Design thinking as a tool box] edited by M. Nowak ",Człowiek i Społeczeństwo" vol. XLVIII: Kuchnia badań miejskich. Studia na temat praktyki empirycznej badaczy miasta [A backstage of urban research. Studies on the empirical practices of city research scientists], Poznań 2019, pp. 75-90, Adam Mickiewicz University. ISSN 0239-3271.
\end{abstract}

The paper discusses design thinking methodology, arguing that this perspective may be useful for sociology, particularly urban sociology. The author demonstrates that design thinking tools are similar to some sociological research tools.

Marta Skowrońska, Uniwersytet im. Adama Mickiewicza w Poznaniu, Wydział Socjologii, ul. Szamarzewskiego 89, 60-568 Poznań, skowronska.marta@gmail.com

\section{Czym jest design thinking - wprowadzenie}

Design thinking (DT) to hasło, które od lat osiemdziesiątych ubiegłego wieku robi spektakularną karierę, przede wszystkim w polu biznesu. Początkowo rozumiana bardziej jako podejście w pracy projektantów/designerów, obecnie metodyka design thinking traktowana jest przede wszystkim jako interdyscyplinarne podejście służące wytwarzaniu innowacyjnych rozwiązań czy też kultura pracy, która ma prowadzić do wytwarzania nowych jakości. W Polsce ta metodyka pracy obecna jest od stosunkowo niedawna. Można uznać, że przełomem było ukazanie się polskiego przekładu książki Tima Browna (2013) - osoby, która ugruntowała pojęcie design thinking 
i spopularyzowała je. Od tego momentu nastąpił wysyp publikacji dotyczących myślenia projektowego (m.in. Arabasz i Sińczuch, 2016; Baran i Lewandowski, 2017; Ćwikliński, 2017; Helman i Rosienkiewicz, 2016; Brodnicki, 2015). Publikacje dotyczyły przede wszystkim funkcjonowania przedsiębiorstw, rozwoju przedsiębiorczości, zarządzania i planowania. Powoli zaczęły jednak pojawiać się też próby aplikacji design thinking na innych polach niż biznesowe: Renata Staśko (2018) analizowała zastosowanie myślenia projektowego w edukacji szkolnej, a Magdalena Wróbel-Lachowska i Andrzej Romanowski (2015) omawiali projektowanie usług dla seniorów.

W tym artykule pokażę użyteczność myślenia projektowego wykraczającą poza kontekst biznesowy. Na wstępie zdefiniuję, czym jest design thinking, wskazując na powiązania tej perspektywy z niektórymi nurtami metodologicznymi w socjologii. Wskażę również na pewne cechy design thinking, które mogą wydawać się socjologom ryzykowne. W następnej części artykułu omówię kolejne etapy pracy w metodologii design thinking i charakterystyczne dla nich narzędzia, porównując je z innymi, znanymi już socjologom technikami badawczymi. Omówię też myślenie projektowe jako użyteczne narzędzie w rękach socjologa badającego kwestie miejskie.

Definicja design thinking przysparza pewnych trudności z kilku powodów. Przede wszystkim wynika to z genezy tego pojęcia. Powszechnie panującym przekonaniem jest to, że DT zostało „stworzone” przez Tima Browna na Uniwersytecie Stanforda. We wstępie do polskiego przekładu Browna (2013) Mariusz Wszołek i Michał Grech wskazują jednak słusznie na to, że rola Browna polegała raczej na zebraniu i uporządkowaniu pewnych nurtów obecnych w projektowaniu - takich jak projektowanie partycypacyjne, myślenie dywergencyjne, burza mózgów - i spięciu ich w spójny koncept oraz nadaniu im nazwy, jak się później okazało, bardzo chwytliwej. Nie oznacza to, że rola Browna była marginalna - wręcz przeciwnie. Dzięki niemu zbiór postaw, perspektyw, nastawień, sposobów pracy oraz konkretnych narzędzi został przekuty na konkretną metodykę pracy projektowej, którą można rozpatrywać na trzech poziomach: (1) DT jako pewna perspektywa, podejście do rozwiązywania problemów; (2) DT jako procedura pracy składająca się z kilku określonych faz; (3) DT jako zbiór narzędzi, które można wykorzystywać w poszczególnych fazach pracy.

Jeśli chodzi o pewną ogólną perspektywę pracy, w DT można wyróżnić kilka podstawowych założeń: orientację na człowieka, partycypację, interdyscyplinarność, cyrkularność i nieprzewidywalność, double diamond (podwójny diament) oraz myślenie przez działanie. Human-centered design - orientacja na człowieka - może wydawać się socjologowi banalnym stwierdzeniem. 
Czy projektowanie nie jest zawsze skoncentrowane na człowieku i jego potrzebach? Czy badania społeczne i marketingowe nie dotyczą potrzeb?

Rzeczywiście, samo hasło „człowiek jest najważniejszy” to jedynie klisza. Przełożone na konkretne procedury działania i organizacji - niekoniecznie się sprawdza. W przypadku DT orientacja na człowieka oznacza pogłębiony wgląd (insight) i empatię. Przekładając tę perspektywę na pole socjologii, można zobaczyć oczywiste związki z podejściem antynaturalistycznym, a więc m.in. z socjologią rozumiejącą („współczynnik humanistyczny" Znanieckiego), konstruktywizmem społecznym: etnometodologią i fenomenologią, przekładającą się na jakościowe metody badań. Czytając o podejściu skoncentrowanym na człowieku w DT, można zauważyć także związki z postmodernistycznymi orientacjami metodologicznymi, które coraz mocniej dążą do obalenia bariery badacz-badany, co wyraża się choćby w zmianie nazewnictwa (,informator”, a obecnie wręcz „współpracownik”), nacisku na autoetnografię, wyczuleniu na kwestie etyczne. W przypadku DT empatia i wgląd - co istotne - zakłada jeszcze więcej niż podejście jakościowe i rozumiejące. Ważne, by przyglądanie się z bliska ludzkim działaniom nie było ograniczone do statystycznego reprezentanta badanej grupy. To, co jest projektowane, ma bowiem nie tylko zaspokoić „,przeciętne” potrzeby, ale również potrzeby wyjątkowych, mniejszościowych grup: niepełnosprawnych, seniorów, dzieci, osób z innego kręgu kulturowego. Empatia i wgląd przekładają się też na stosowanie konkretnych narzędzi, omówionych w dalszej części artykułu.

Założenie o partycypacji oraz interdyscyplinarności bliskie jest trendom obecnym w naukach społecznych. Podobnie jak w świecie akademickim, który coraz częściej zauważa, że wykroczenie poza granice dyscyplin pomaga rozszerzyć perspektywę badawczą i pozwala na kontekst odkrycia, w metodzie projektowej silne jest założenie, że jedynie interdyscyplinarność daje szansę na innowację. DT zakłada, że innowacja nie jest możliwa bez pracy interdyscyplinarnego zespołu, którego skład wykracza poza tradycyjnie rozumianą eksperckość. Interdyscyplinarność jest więc zarazem bliska partycypacji. Podstawą działania w metodyce DT jest dobrze zbudowany zespół. W jego skład wchodzą przedstawiciele nauki, biznesu, sztuki, a także eksperci codzienności. Ekspertem od spraw miasta będzie zatem nie tylko urzędnik, socjolog, aktywista miejski, urbanista, planista, architekt czy deweloper - będzie nim również, a może przede wszystkim, mieszkaniec, budowlaniec, kierowca autobusu, sprzedawca na targu. Słowo „partycypacja” jest oczywiście odmieniane przez wszystkie przypadki nie tylko przez przedstawicieli DT. Szczególnie kontekst działań miejskich mocno zanurzony 
jest w ideę współuczestnictwa i współtworzenia, co widać na przykładzie konsultacji społecznych, budżetów obywatelskich, referendów. Tego rodzaju tendencje obecne sa, rzecz jasna, od lat w planowaniu partycypacyjnym i designie partycypacyjnym. Jacek Kotus (2014: 38) przytacza wiele angielskich zwrotów powiązanych z tym nurtem: deliberative planning, collaborative planning, communicative planning, public participation. Czy DT wnosi coś nowego do tego zestawu? Siła tej metodyki wyraża się w przełożeniu ogólnych trendów na wyraźne procedury. Specyfika pracy interdyscyplinarnego zespołu projektowego w DT polega na tym, że omówiona wyżej grupa ekspertów (w rozumieniu tradycyjnym i nowym rozumieniu - jako ekspertów od życia codziennego) pracuje od początku do końca nad rozwiązaniem konkretnego problemu. Nie jest więc na przykład tak, że mieszkańcy miasta bywają zapraszani na pojedyncze spotkania w sprawie przeprojektowania miejskiego targu - uczestniczą oni w procesie projektowym od etapu badawczego do ostatecznego zaakceptowania briefu projektowego (więcej na temat etapów procesu w dalszej części artykułu). To silne założenie o pracy całego interdyscyplinarnego zespołu wypływa z przekonania o kolektywnym tworzeniu się wiedzy i konieczności przesunięcia akcentów z indywidualnych osiągnięć na wspólne wypracowywanie celu.

Cyrkularność i nieprzewidywalność to cechy DT, które bywają problematyczne dla uczestników procesu, przede wszystkim zaś - dla decydentów, planistów, polityków czy szefów firm. Idea projektowania DT zakłada w miejsce linearnego procesu problem-działanie-rozwiązanie ciągłe krążenie: od problemu do rozwiązania, a od rozwiązania do wyodrębnienia kolejnego problemu. W zasadzie proces projektowy nigdy się nie kończy. Rozwiązanie to punkt wyjścia dla podjęcia na nowo problemu projektowego (Brown, 2013). Ponadto na każdym etapie procesu projektowego może zdarzyć się tak, że trzeba będzie cofnąć się do wcześniejszych etapów. W związku z tym bardzo trudne jest zaplanowanie całości procesu w czasie. Szczególnie trudna dla uczestników jest nieprzewidywalność procesu. DT zakłada, że nie jesteśmy w stanie przewidzieć, dokąd zaprowadzi nas działanie projektowe - co trzeba będzie jeszcze zbadać, co zaprototypować, co zweryfikować. Ten sposób myślenia socjologom kojarzy się z pewnością z teorią ugruntowaną (Charmaz, 2009; Konecki, 2000). To podejście, zakładające, że teoria „wyłania się” z terenu, również jest problematyczne ze względu na niemożność dokładnego zaplanowania czynności badawczych, ponadto zakłada „krążenie” między danymi aż do osiągnięcia empirycznego nasycenia. Pomimo problematyczności tych założeń dobrze przystają one do charakteru procesu badawczo-projektowego. Eksploracja problemu i próby 
jego rozwiązania są bardzo trudne do oszacowania - można oczywiście poruszać się wyłącznie w obrębie ściśle wyznaczonych ram czasowych, finansowych, logistycznych - często oznacza to jednak konieczność redukcji danych, uproszczeń i kompromisów. Pragmatyka procesów badawczo-projektowych jest na ogół skonfliktowana z logiką finansowania - praca od projektu do projektu nie pozwala na ciągłość i cyrkularność.

Kolejną cechą metodyki pracy DT jest tak zwany „podwójny diament” (double diamond), który można również określić jako następujące po sobie procesy dywergencji i konwergencji, rozszerzania i zawężania.

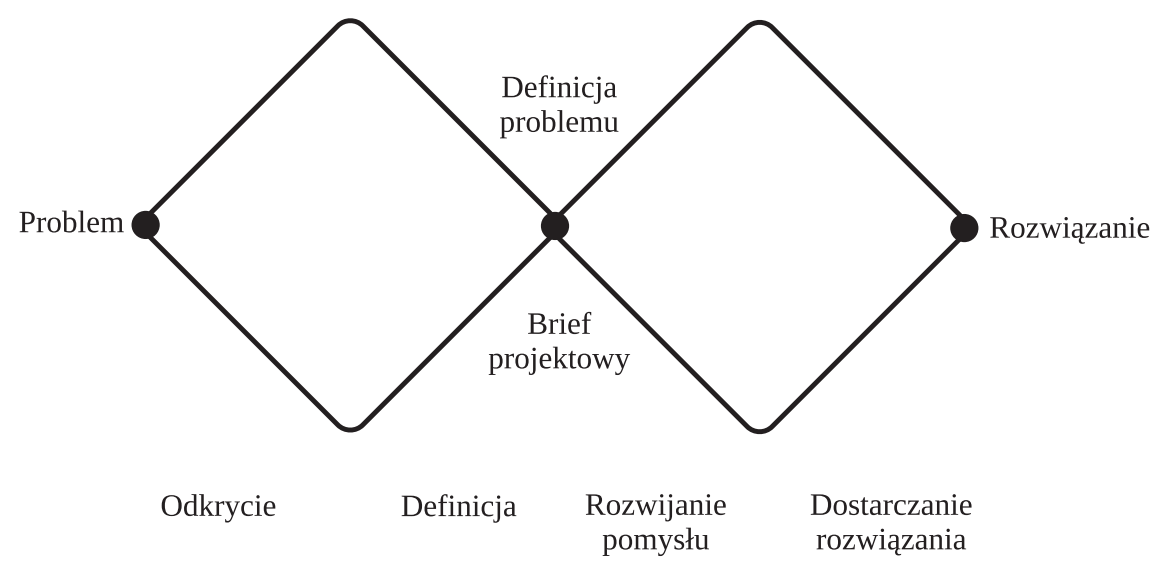

Rysunek 1. Podwójny diament

Źródło: opracowanie własne na podstawie https://www.designcouncil.org.uk/sites/default/ files/asset/document/ElevenLessons_Design_Council\%20(2).pdf, dostęp: 15.12.2019.

Pracę nad projektem zaczyna się od maksymalnego rozszerzania perspektywy i kontekstów, następnie dokonuje się procesu selekcji i redukcji, po czym wyselekcjonowane konteksty po raz kolejny się rozszerza. W dalszej części artykułu zaprezentuję konkretne narzędzia, które temu służą. Istotne jest to, że w zasadzie na każdym etapie pracy obowiązuje zasada „myślenia przez działanie”. To założenie, jeśli chcielibyśmy przekuć je na teorie socjologiczne, bliskie jest tzw. practice turn i pragmatic turn (zwrot ku praktykom; Reckwitz, 2002; Schatzki, 2001), a także docenieniu roli ciała i ruchu w procesie kognitywnym (m.in. Engel, Maye, Kurthen i König, 2013). W myśleniu projektowym myślenie przez działanie przekłada się na bardzo wczesne prototypowanie pomysłów. W przeciwieństwie do klasycznego procesu projektowego, w którym po długim etapie dyskutowania, konsultowania i sporów finalnie dochodzi się do faktycznego zaprojektowania usługi, 
miejsca czy przedmiotu, w DT projektowanie obecne jest w sposób ciągły. Prototypy tworzone są tanio i szybko, ponieważ powstaje ich bardzo wiele i są nieustannie udoskonalane. Założenie jednak jest takie, że to w działaniu tworzeniu, rysowaniu, klejeniu, programowaniu czy rzeźbieniu - możliwe jest przełamanie barier myślowych, uruchomienie kreatywności i dojście do innowacyjnych rozwiązań. Poza prototypowaniem myślenie przez działanie to też szersze podejście do badań - nie wystarczy rozmowa, potrzebne jest wejście w interakcję z materią, technologią, środowiskiem, ponieważ wiedza ma charakter ucieleśniony i usytuowany (o relacjach między projektowaniem a teoriami praktyki ciekawie pisze Lucy Kimbell, 2009).

\section{Etapy procesu DT}

Jak wygląda proces design thinking w praktyce, jakie są jego etapy? Każdy podręcznik DT powtarza za Timem Brownem, że etapów jest pięć: empatyzacja, definiowanie, tworzenie pomysłów, prototypowanie i testowanie przy założeniu iteracyjności, a więc powtarzania poszczególnych operacji.

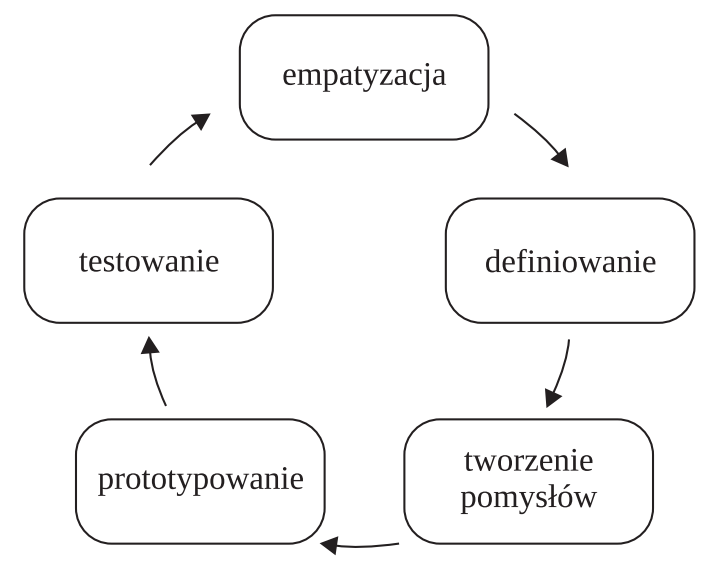

Rysunek 2. Etapy procesu design thinking

Źródło: opracowanie własne.

Omówię je kolejno, prezentując też charakterystyczne dla każdego etapu narzędzia. Istotniejsze od szczegółów tych etapów wydaje się jednak to, o czym wspomniałam już wcześniej, a mianowicie bardzo kompleksowo rozumiany proces partycypacyjny. Wyobraźmy sobie, że celem procesu badawczo-projektowego jest stworzenie nowego skweru w miejscu, w którym 
do tej pory znajdował się nieużytek. Partycypacja lokalnej społeczności nie będzie polegała na konsultacji. Wybrani przedstawiciele społeczności będą zaproszeni do zespołu projektowego, który wspólnie przechodzić będzie przez kolejne fazy. W tym zespole będą starannie dobrani eksperci - dobór będzie musiał uwzględnić kilka czynników. Uczestnicy będą musieli wzajemnie się uzupełniać kompetencjami „twardymi” - wiedzą i doświadczeniem w określonym obszarze oraz „miękkimi” - potrzebne będą osoby mające skłonność do porządkowania wiedzy, jak i te, które cechuje skłonność do komplikowania i znajdywania potencjalnych problemów, oraz te, które z entuzjazmem szukają nowych rozwiązań. Zespół badawczo-projektowy będzie zajmować się wszystkim, bez podziału ról. Będą natomiast potrzebne określone kompetencje poszczególnych członków zespołu po to, by wyposażyć zespół jako całość. W przytoczonym przykładzie na pewno będziemy potrzebować „ekstremalnych użytkowników” - osób, które będą korzystać ze skweru intensywnie, mając zarazem bardzo określone potrzeby - rodziców z małymi dziećmi w wózkach, osób z ograniczoną mobilnością, właścicieli psów, młodzież uprawiającą sport, seniorów. Będą potrzebni, rzecz jasna, architekci i urbaniści, projektanci zieleni. Będą potrzebni przedstawiciele lokalnego samorządu i lokalni aktywiści. Wreszcie niezwykle istotna jest obecność badaczy - socjologów, antropologów, psychologów - którzy pomogą całemu zespołowi przejść przez fazę eksploracji i podsumowania badań.

Pierwszy etap to empatyzacja. Rola socjologa - badacza miasta jest na tym etapie nie do przecenienia. Jest to faza, w której wszyscy członkowie zespołu muszą wczuć się w sytuację użytkownika, szczególnie tego, który ma specyficzne potrzeby (jest dzieckiem, niepełnosprawnym, osobą starszą). Aby to zrobić, stosuje się wiele narzędzi, z których część jest dobrze badaczom społecznym znana. Najważniejsze są tu: obserwacja i autoetnografia. Aby przebiegły bardziej intensywnie, wspomaga się je dodatkowymi technikami. Jedną z nich jest tzw. service safari. To narzędzie stanowi połączenie autoetnografii z analizą danych zastanych - polega na tym, że członkowie zespołu badawczo-projektowego odwiedzają możliwie największą liczbę miejsc oferujących usługę podobną do projektowanej, starając się jak najbardziej wejść w rolę użytkownika. Kiedy zespół IDEO projektował przestrzeń szpitalną, uczestnicy projektu przechodzili przez cały proces rejestrowania się do różnych przychodni i szukania pomocy u specjalistów¹ ${ }^{1}$.

${ }^{1}$ Na gruncie nauki pogłębiona etnografia i autoetnografia są oczywiście znane - jak choćby słynny przypadek fikcyjnej pracy Ervinga Goffmana jako asystenta w szpitalu psychiatrycznym (Goffman, 2011). 
Dobrze, jeśli proces doświadczania celowo się utrudni - pójdzie się z walizką, o kulach, z dzieckiem w wózku. Wykorzystuje się też znaną w marketingu technikę shadowing czy znaną z animacji kulturowej technikę spaceru badawczego. Odwiedza się więc różne miejsca z drugą osobą, zadając jej jednocześnie pytania. Wywiady pogłębione, które również się stosuje, najczęściej mają charakter kontekstowy (w najważniejszym miejscu czy podczas wykonywania głównej czynności) i wsparte są technikami wizualnymi oraz pobudzającymi pamięć. Stosuje się więc dzienniczki tradycyjne i elektroniczne, fotografię, mapy. Metody ilościowe należą do rzadkości na tym etapie. Pewnym rodzajem ankiety są tak zwane graffiti walls, a więc udostępnienie ściany (przez pokrycie ją papierem lub danie możliwości pisania kredą po murze) jako miejsca, gdzie spontanicznie można umieścić swoje przemyślenia na jakiś temat. Interesującą techniką wspomagającą wywiad jest też triading - proste narzędzie służące wydobyciu głębiej ukrytych postaw i odczuć dotyczących usług, miejsc czy produktów. Badanym pokazuje się każdorazowo trzy elementy (takich zestawów może być wiele) - np. zdjęcia trzech parków lub trzech przychodni lekarskich - i prosi o to, by każdorazowo wskazali jeden element, którym dany obiekt różni się od dwóch pozostałych. W tym procesie uwidaczniają się kryteria oceny, sposoby percepcji, schematy myślowe, które mogłyby w innym przypadku pozostać ukryte.

Bardzo istotne jest to, że na etapie empatyzacji eksploracja dotyczy sposobów używania przestrzeni i przedmiotów, sposobów myślenia, odczuwania, postrzegania, a także problemów, które badani napotykają na drodze - nie sprowadza się natomiast do typowego dla badań marketingowych badania potrzeb. Brown przytacza często bardzo sugestywny cytat z Henry’ego Forda dotyczący wynalezienia samochodu - gdyby pytać ludzi co należałoby wynaleźć, powiedzieliby, że szybszego konia (Brown, 2013: 46). Ludzie poruszają się bowiem w znanych sobie schematach myślowych. Zamiast pytać, czego chcą, lepiej pytać (i obserwować), jak radzą sobie w tej chwili, z czym mają problem, co czują. Jak pisze dalej Brown:

Dlatego właśnie tradycyjne techniki badawcze, takie jak grupy fokusowe czy badania surveyowe, podczas których zwykle pyta się ludzi, czego chcą, rzadko przynoszą jakieś znaczące spostrzeżenia. Narzędzia konwencjonalnych badań rynku przydają się do wskazywania kierunku inkrementalnych ulepszeń, ale nigdy nie doprowadzą do zmieniających zasady gry i obalających paradygmaty przełomowych odkryć, które sprawiają, że drapiemy się po głowie i zastanawiamy, dlaczego nikt wcześniej na to nie wpadł (Brown, 2013: 68). 
Dla etapu empatyzacji ważne jest też zdefiniowanie wszystkich aktorów, którzy mają wpływ na charakter badanego procesu/usługi/miejsca/ przedmiotu. Wykorzystuje się przy tym narzędzie nazywane mapą interesariuszy - można ich grupować na różne sposoby, np. definiując stopień ich wpływu na dany proces czy stopień ich zaangażowania. Dzięki temu działaniu zmniejszymy ryzyko pominięcia pewnych kontekstów mających wpływ na badane procesy. Może się okazać, że przy projektowaniu niezbędne jest objęcie badaniem pewnych osób i instytucji, których początkowo nie brano pod uwagę.

Etap empatyzacji/eksploracji jest w „,podwójnym diamencie” momentem dywergencji - kolejnym jest konwergencja, a więc moment definiowania. Oznacza to, że zespół projektowy porządkuje obserwacje i próbuje zdefiniować podstawowe problemy do rozwiązania. Ten proces ma charakter zespołowy. Często korzysta się z bardzo prostego narzędzia zwanego affinity diagram diagramu podobieństw (np. Hanington i Martin, 2012: 12). Ten żmudny, ale efektywny sposób polega na tym, że członkowie zespołu indywidualnie zapisują najważniejsze obserwacje na samoprzylepnych kartkach (post-it), a następnie wspólnie przyklejają je na ścianę, szukając podobieństw i grupując obserwacje w klastry. Choć socjologowie na ogół wolą posługiwać się programami do kodowania i analizowania danych jakościowych, jak Nvivo, Atlas czy MAXQDA, ten analogowy model pracy ma wiele zalet. Pozwala na warsztatowy, dialogiczny sposób pracy - wymaga ciągłego uzgadniania znaczeń, negocjowania sensów i ciągłej konfrontacji własnych obserwacji z obserwacjami innych. Inaczej mówiąc, jest to sposób na zwiększenie refleksyjności poprzez ciągłe konfrontowanie z inną opinią i szukanie kompromisu. W przypadku projektowania usługi bardzo użytecznym narzędziem jest customer journey map - mapa podróży użytkownika. Polega ona na uporządkowaniu działań i doświadczeń związanych z usługą w formie diagramu, na którym (na podstawie wyników eksploracji) definiuje się kolejne kroki użytkownika wchodzącego w kontakt z usługą jako tzw. punkty styku (touchpoints). Oznaczają one interakcję z innym człowiekiem lub materialnością, które wpływają na sposób myślenia i odczuwania danej usługi. Jeśli projektujemy skwer, może być to np.: przejście przez furtkę, kupno lodów w budce, siedzenie na ławce, ćwiczenia na siłowni na powietrzu, rozmowa z sąsiadem, zjedzenie kanapki, wyrzucenie opakowania, wyjście ze skweru. Dla każdego z tych punktów należy dodatkowo zdefiniować kanały (channels) komunikacji/interakcji - naciśnięcie klamki, rozmowa z pracownikiem. Definiuje się dokładnie wszystkie czynności, jakie są wykonywane, a następnie emocje, jakie się z nimi wiążą. Definiuje się także problemy pojawiające się 
na danym etapie. Można również wklejać zdjęcia, jeśli były robione podczas obserwacji, oraz dopisywać cytaty z wypowiedzi użytkowników. Definiuje się też czynności wykonywane przez innych aktorów widoczne dla użytkownika (np. osoba sprzątająca skwer) oraz te niewidoczne, a jednak istotne (dziejące się „poza sceną” - np. w nocy, w godzinach zamknięcia). Mapa podróży użytkownika jest narzędziem, które zarazem pozwala wkroczyć na kolejny etap (o którym będzie mowa za chwilę) - generowania pomysłów. Na ogół bowiem mapę uzupełnia się o obserwacje związane z potencjalnymi usprawnieniami poszczególnych etapów podróży, pomysłami na innowację.

Innym narzędziem porządkującym wyniki eksploracji jest behavioral mapping - mapa zachowań (Hanington i Martin, 2012: 18). Na przestrzenny schemat, obrazujący np. skwer, przychodnię czy sklep, nanoszone są wszystkie zachowania obserwowane w konkretnych miejscach - zagregowanie tych czynności pozwala wysnuć wnioski co do relacji między tym, co zaprojektowane, a faktycznymi działaniami.

Narzędzi porządkujących obserwacje jest więcej. Nie mając miejsca na to, by opisać wszystkie, wspomnę na koniec o mapach empatii i personach narzędziach najbardziej chyba znanych, które polegają na naszkicowaniu schematycznych portretów pewnych typów osób, np. użytkowników usługi. Tym typom na ogół nadaje się imiona, przypisuje pewien wygląd, cechy społeczno-demograficzne, a następnie zastanawia się nad ich potrzebami i problemami. Omówienie tych narzędzi wydaje mi się ważne dlatego, że dość często są one wykorzystywane w sposób błędny. Uczestnikom warsztatów każe się tworzyć persony lub mapy empatii jako punkt wyjścia dla badań, nie zaś ich podsumowanie - wskutek czego stanowią one odbicie stereotypowych przekonań i niewiele wnoszą do procesu projektowego. Persony i mapy empatii są tymczasem dobrym narzędziem podsumowującym. Po fazie eksploracyjnej dobrze jest podsumować wszystkie wyłaniające się typy aktorów po to, by analizować charakterystyczne dla nich problemy i zastanawiać się nad ich rozwiązaniem.

Po etapie definiowania (konwergencja) następuje trzeci etap - generowania pomysłów (dywergencja). Podobnie jak w przypadku fazy empatyzacji (również dywergencja), celem jest maksymalne rozszerzanie i pogłębianie w tym przypadku służące wygenerowaniu kreatywnych rozwiązań. Techniki wykorzystywane na tym etapie budują pomost między wnioskami wygenerowanymi w fazie definiowania a kolejną fazą - tworzenia prototypu. Jedną z takich technik jest ELITO (Hanington i Martin, 2012: 70). Członkowie zespołu, wyselekcjonowawszy najistotniejsze obserwacje z badań, wpisują je w tabelę jedna pod drugą, a następnie uzupełniają matrycę o następujące elementy: swoje opinie/wnioski dotyczące obserwacji (judgement), 
najistotniejsze wartości wiążące się z zaobserwowanym zjawiskiem (value), kierunek projektowy dla rozwiązania zaobserwowanego problemu (concept) oraz metaforę kierującą w stronę rozwiązania. Innym narzędziem jest oś kierunków rozwoju, w której wyodrębnione w fazie empatyzacji główne wartości stają się podstawą budowania uogólnionych kierunków rozwiązań. Najpowszechniejsze na tym etapie jest po prostu tworzenie scenariuszy projektowych - wstępnych pomysłów na innowacje, najpierw indywidualnie, potem - jak w etapie definiowania - poprzez szukanie podobieństw (klastrów). Ten etap kończy się kolejną konwergencją - wyborem jednego scenariusza projektowego (będącego na ogół syntezą kilku, kilkunastu innych), a następnie (etap czwarty) - budowaniem prototypu.

W metodyce DT prototypowanie jest bardzo istotne - uważa się, że innowacje powstają w działaniu. W związku z tym prototyp tworzy się szybko i tanio, z założeniem, że jest on roboczym narzędziem do testowania i z pewnością pojawiają się kolejne prototypy. Sposobów prototypowania jest wiele - od budowania z klocków, przez klejenie, lepienie z modeliny i gliny, rysowanie, tworzenie makiet, aż po odgrywanie scenek. Kluczowe jest to, by prototyp był zrozumiały, czytelny dla odbiorcy, któremu trzeba go przedstawić. Główną rolą prototypu jest bowiem bycie testowanym - wejście w interakcję z odbiorcą. W zależności od rodzaju prototypu sposobów testowania jest kilka. Może to być wywiad kontekstowy, obserwacja, dzienniczek. Jedną z ciekawszych technik jest użycie cultural probes, metody wynalezionej pod wpływem artystycznego ruchu sytuacjonistów (Gaver, Dunne i Pacenti, 1999). Polega ona na przygotowaniu zestawów przedmiotów wraz z zadaniami do wykonania dla respondentów. W przypadku prototypu zadanie może polegać na tym, by używać prototypu w konkretnych sytuacjach i nagrywać/notować te zdarzenia. Testowanie może też przybierać formę eksperymentu - w kontekście miejskim można potraktować w ten sposób Parking Day. To, co dzieje się w mieście przy okazji Parking Day, mogłoby być testowaniem prototypu - jak zachowają się użytkownicy, gdy parking zostanie zamieniony w siedzisko, huśtawkę lub punkt wymiany ubrań.

\section{Przykłady zastosowania metodologii design thinking w projektowaniu miejskich usług}

W tym miejscu chciałabym przedstawić kilka przykładów użycia narzędzi zaczerpniętych z metodologii design thinking do projektowania miejskich usług. Pierwszy przypadek to działanie (na niewielką, co prawda, skalę), 
jakie zostało podjęte przez Towarzystwo Inicjatyw Twórczych Ę w Warszawie we współpracy z grupą socjologów w ramach projektu „Generator innowacji. Sieci wsparcia”. Ideą projektu było stworzenie innowacji - usługi dla mieszkańców miasta - która odpowiadałaby na potrzeby osób starszych zależnych. Ogłoszono konkurs na innowacje w tym obszarze, do którego zgłosiły się osoby z różnych środowisk, reprezentujące różnego rodzaju podmioty (osoby indywidualne, grupy nieformalne, organizacje pozarządowe, firmy, instytucje publiczne, jednostki samorządowe). W pierwszej fazie (empatyzacja) zadaniem socjologów była pomoc innowatorom w pogłębieniu wiedzy na temat grupy, dla której projektowana jest innowacja (desk research). Oprócz tego z pomocą mentorów (eksperci w tematyce) innowatorzy poszukiwali inspiracji do swoich projektów, rozpoznawali problem. Następnie przy wsparciu socjologów i mentorów przeprowadzali badania mające na celu rozpoznanie potrzeb grupy docelowej. Kolejnym etapem było sprecyzowanie problemu, którego rozwiązanie będzie chciał znaleźć innowator (definicja) i stworzenie pomysłu oraz przekucie go na prototyp rozwiązania (faza tworzenia pomysłów i prototypowania). Innowatorzy zostali zaproszeni na Targi Innowacji, na których była możliwa wymiana wiedzy, doświadczeń i inspiracji oraz dopracowanie pomysłu (pierwsza iteracja). Następnie z pomocą socjologów sprawdzano, jak prototyp działa zaangażowano do tego osoby starsze zależne i ich opiekunów (faza prototypowania). Była to zarazem ewaluacja projektu (ewaluacja typu on-going), po której następowała kolejna iteracja i dopracowanie idei. W kolejnym etapie eksperci i badacze opracowywali dokument - analizę warunków implementacji pomysłów - i dokonywali wyboru najlepszych innowacji. W procesie wyboru ściśle współpracowali badacze, mentorzy i eksperci. Dopiero po tym etapie opracowywano ostateczną wersję innowacji i wdrażano ją. Innowacje są otwarte dla wszystkich na zasadzie wolnej licencji. Zwycięskie pomysły były trzy. Arkadiusz Wybranowski z Bydgoszczy stworzył rozwiązanie „polegające na audycie społecznym (prowadzonym przez aktywnych seniorów) umożliwiające przeprowadzenie zmian i dostosowanie mieszkania do potrzeb osoby starszej przy zaangażowaniu lokalnej społeczności. Model ten ma odkrywać, jakie bariery architektoniczne i ergonomiczne ograniczają ich samodzielność i powodują wykluczenie społeczne” (Projektanci..., 2019). Sq̨iedzka Kieszeń Wsparcia została opracowana przez Natalię Gołubowską oraz Annę Stelmarczyk-Matraj z Wołowa. Inicjatywa ta polega na opracowaniu systemu umożliwiającego komunikację oraz wymianę wzajemnych usług pomiędzy osobą starszą zależną, jej najbliższymi sąsiadami z klatki schodowej oraz lokalnymi 
instytucjami kultury. Trzeci projekt, autorstwa Magdaleny Katany i Ewy Hiller, Torba Borba, to system dzielenia specjalnego wózka na zakupy, umożliwiający seniorom nie tylko samodzielne zakupy, ale i nawiązanie więzi w lokalnej społeczności.

Innym przykładem, spoza polskiego kontekstu, jest fiński projekt ARJA (Wallin i Horelli, 2010), którego celem była poprawa jakości życia rodzin w dwóch miastach, zwłaszcza w zakresie proporcji czasu pracy i czasu poświęcanego rodzinie. W pierwszym etapie przeprowadzono liczne badania, w których poza klasycznymi technikami stosowanymi w naukach społecznych (ankieta, IDI, dzienniczki, desk research) prowadzono też warsztaty - z mapowaniem, tworzeniem ścieżek, budowaniem modeli; chodzono na spacery badawcze. Do tych badań zaangażowano dwadzieścia rodzin (grupa pilotażowa). Zdefiniowano główne problemy, jakie wyłoniły się w trakcie badań: problemy z dowożeniem dzieci na zajęcia dodatkowe, opieką po szkole i bezpieczeństwem w metrze. Ukształtowało się forum sąsiedzkie, które razem z grupą zaangażowanych ekspertów stworzyło prototypy jedenastu projektów. Efektem projektu jest nie tylko nowo tworzona usługa - rodzaj help desk, które będzie umiejscowione w odnowionej stacji metra, wraz z biblioteką i miejscem zabaw dla dzieci - ale i zaktywizowana i zintegrowana grupa mieszkańców, zaczątek prężnej lokalnej wspólnoty.

\section{Podsumowanie}

Design thinking rozumiany jako zbiór technik, do których użycia niezbędne są samoprzylepne karteczki, nie wniesie wiele do skrzynki narzędziowej badacza miasta. Najistotniejsza dla tej metodyki jest bowiem zmiana sposobu myślenia o projektowaniu (miasta i nie tylko). Na ogół, mówiąc o designie i projektowaniu, myślimy o postaci eksperta - architekta, projektanta, artysty, o grupie decydentów oraz o odbiorcach, których zaprasza się do konsultacji. Badania są zwykle dodatkiem do procesu. Wykonuje je badacz lub grupa badaczy, dostarczający decydentom raport, którego dalsze losy bywają różne - może być on inspiracją, wsparciem, a może być też uzasadnieniem dla arbitralnych decyzji. Proces pracy w metodyce DT zakłada zniesienie dotychczasowych podziałów na odbiorców i nadawców procesu projektowego. Pracuje się w interdyscyplinarnym zespole, w którym wszyscy - i architekci, i urzędnicy, i mieszkańcy - stają się badaczami oraz projektantami. Taka zmiana perspektywy wykracza jeszcze trochę ponad założenia designu partycypacyjnego, 
jest radykalnym odwróceniem modernistycznego modelu budowania „idealnych” budynków czy osiedli, które nierzadko okazywały się niedostosowane do potrzeb i kontekstu (Chapman i Hockey, 1999; Heynen i Baydar, 2005).

Metodyka DT daje też badaczowi miasta nową rolę. Pozwala mu wyrwać się z granic własnej dyscypliny, roli eksperta, który zakleszczony w granicach swojego pola (Bourdieu, 2006) może jedynie dostarczyć wyników badań, przy czym przełożenie tych badań na realne działania nie zawsze będzie możliwe, choćby ze względu na różne logiki pól (nauki i władzy). Ewa Zielińska w swoim bardzo ciekawym artykule „Design thinking”. Model pracy badawczej w obliczu dzikich problemów społecznych (2013) zauważa, że

model zdominowany przez myślenie liniowe, prowadzący od specjalistycznej diagnozy przez realizację badań aż po wdrożenie, gdzie na każdym etapie pracują inni specjaliści, a raz powzięte decyzje i zaproponowane rozwiązania nie są weryfikowane, nie przystaje do wyzwań określonych przez Rittela jako wicked, „dzikie” - w odróżnieniu od „oswojonych” problemów nauk ścisłych (Rittel Webber, 1973: 160). W sytuacji, gdy na każdym etapie realizowania projektu pojawiają się nowe dane, nowe fakty i nowi aktorzy, całkowicie bezzasadne, żeby nie powiedzieć bezsensowne, jest opieranie się jedynie na wstępnej idei, diagnozie, propozycji lub zamówieniu, niemodyfikowanych w toku pracy. [...] Rozwiązaniem wielu problemów są proste pomysły, a te nie powstaną, gdy jedynym punktem styku między ich możliwym wykonawcą (np. designerem) a badaczem będzie profesjonalny, wyczerpujący i ignorowany przez środowiska pozanaukowe - raport. Czasem konieczne jest bowiem, by między designerem a badaczem doszło do konfrontacji, a nawet kłótni, podczas których wnioski zawarte w raporcie trafią mimochodem na podatny grunt (Zielińska, 2013: 171).

Wyzwania, jakie stawiają przed nami szybko zmieniające się środowiska współczesnych miast, wymagają nowych sposobów pracy i nowych sposobów badań. Metodyka design thinking może się okazać pomocna w rozwiązywaniu współczesnych problemów miejskich ze względu na swoją elastyczność, inkluzywność, holistyczną perspektywę i głęboko interdyscyplinarny charakter. Chociaż wiele jej narzędzi nawiązuje do znanych już socjologom podejść i technik, warto przyjrzeć się tej metodyce całościowo, jako głęboko humanistycznemu, empatycznemu procesowi, którego celem jest zaprojektowanie miejsc, przedmiotów i usług rozwiązujących rzeczywiste problemy. 


\section{Literatura}

Arabasz, M., Sińczuch, M. (2016). Design Thinking. Olsztyn: Uniwersytet Warmińsko-Mazurski.

Baran, G., Lewandowski, M. (2017). Design thinking in public management. W: The Complex Identity of Public Management: Aims, Attitudes, Approaches (ss. 119-134). Kraków: Jagiellonian University Institute of Public Affairs.

Bourdieu, P. (2006). Dystynkcja: społeczna krytyka władzy sq̨zzenia. Warszawa: Wydawnictwo Naukowe Scholar.

Brodnicki, K. (2015). Zastosowanie koncepcji design thinking w funkcjonowaniu przedsiębiorstw. Przedsiębiorstwo we Wspótczesnej Gospodarce - Teoria i Praktyka, 4(14), 35-45.

Brown, T. (2009). Change by Design: How Design Thinking Transforms Organizations and Inspires Innovation. New York: Harper Collins.

Brown, T. (2013). Zmiana przez design: jak design thinking zmienia organizacje i pobudza innowacyjność. Kraków: Libron.

Chapman, T., Hockey, J. (eds). (1999). Ideal Homes? Social Change and Domestic Life. London-New York: Routledge.

Charmaz, K. (2009). Teoria ugruntowana. Warszawa: Wydawnictwo Naukowe PWN.

Ćwikliński, M. (2017). Charakterystyka design thinking przez pryzmat jego instrumentarium. Ekonomika i Organizacja Przedsiębiorstwa: czasopismo poświęcone teorii i praktyce ekonomiki i organizacji przedsiębiorstwa, 7(810), 12-21.

Engel, A.K., Maye, A., Kurthen, M., König, P. (2013). Where's the action? The pragmatic turn in cognitive science. Trends in Cognitive Sciences, 5(17), 202-209.

Gaver, B., Dunne, T., Pacenti, E. (1999). Design: Cultural probes. Interactions, 1(6), 21-29.

Goffman, E. (2011). Instytucje totalne: o pacjentach szpitali psychiatrycznych i mieszkańcach innych instytucji totalnych. Sopot: Gdańskie Wydawnictwo Psychologiczne.

Hanington, B., Martin, B. (2012). Universal Methods of Design. Beverly: Rockport Publishers.

Helman, J., Rosienkiewicz, M. (2016). Design thinking jako koncepcja pobudzania innowacji. W: R. Knosala (red.), Innowacje w zarzq̨dzaniu i inżynierii produkcji (ss. 62-72). Opole: Oficyna Wydawnicza Polskiego Towarzystwa Zarządzania Produkcją.

Heynen, H., Baydar, G. (2005). Negotiating Domesticity: Spatial Productions of Gender in Modern Architecture. Hove: Psychology Press.

Kimbell, L. (2009). Beyond design thinking: Design-as-practice and designs-in-practice. CRESC Conference, Manchester. https://www.researchgate.net/profile/Lucy_Kimbell/ publication/228353351_Beyond_design_thinking_Design-as-practice_and_designs-inpractice/links/02e7e53bf9f1074e34000000.pdf, dostęp: 18.07.2019.

Konecki, K. (2000). Studia z metodologii badań jakościowych: teoria ugruntowana. Warszawa: Wydawnictwo Naukowe PWN.

Kotus, J. (2014). Partycypacja społeczna w zarządzaniu miastem: pomiędzy wykluczeniem społecznym a zaangażowaniem. Studia Miejskie, 13, 37-45. 
Projektanci i designerzy dla osób starszych. (2019). http://e.org.pl/projektanci-i-designerzy-dla-osob-starszych/, dostęp: 15.12.2019.

Reckwitz, A. (2002). Toward a Theory of Social Practices: A Development in Culturalist Theorizing. European Journal of Social Theory, 2(5), 243-263.

Schatzki, T. (2001). Introduction: practice theory. W: K. Knorr-Cetina, The Practice Turn in Contemporary Theory (ss. 10-23). London: Routledge.

Staśko, R. (2018). Warsztaty design thinking jako element samokształcenia uczniów i nauczycieli. Aura, 3(280), 4-5.

Wallin, S., Horelli, L. (2010). The methodology of user-sensitive service design within urban planning. Environment and Planning B: Planning and Design, 37(16) (wersja elektroniczna).

Wróbel-Lachowska, M., Romanowski, A. (2015). Design thinking jako metoda projektowania pozwalająca na poprawę jakości życia osób 50+: na przykładzie programu Destine. W: Ergonomia niepełnosprawnym - projekty poprawiajq̨ce jakość życia (ss. 124-146). Łódź: Wydawnictwo Politechniki Łódzkiej.

Zielińska, E. (2013). Design thinking. Model pracy badawczej w obliczu dzikich problemów nauk społecznych. Stan Rzeczy, 1(4), 168-185. 